\title{
INVESTIGATION OF THE WATER-RETAINING CAPACITY \\ OF THE PROTEIN-HYDROCARBON COMPLEX OF RYE-WHEAT DOUGH WITH ADDITION OF POLYFUNCTIONAL FOOD SUPPLEMENT "MAGNETOFOOD"
}

\author{
Iryna Tsykhanovska \\ Department of food and chemical technologies \\ Ukrainian Engineering-Pedagogics Academy \\ 16 Universitetska str., Kharkiv, Ukraine, 61003 \\ cikhanovskaja@gmail.com \\ Victoria Evlash \\ Department of Chemistry, Microbiology and Food Hygiene \\ Kharkiv State University of Nutrition and Trade \\ 333 Klochkivska str., Kharkiv, Ukraine, 61051 \\ evlashvv@gmail.com \\ Alexandr Alexandrov \\ Department of food and chemical technologies \\ Ukrainian Engineering-Pedagogics Academy \\ 16 Universitetska str., Kharkiv, Ukraine, 61003 \\ alexandrov.a.v.a.v@gmail.com \\ Tetiana Lazareva \\ Department of food and chemical technologies \\ Ukrainian Engineering-Pedagogics Academy \\ 16 Universitetska str., Kharkiv, Ukraine, 61003 \\ Lazareva_T.A@ukr.net \\ Oksana Bryzytska \\ Department of organic chemistry \\ National University of Pharmacy \\ 53 Puschkinska str., Kharkiv, Ukraine, 61002 \\ orgchem@nuph.edu.ua
}

\begin{abstract}
Under modern conditions, creation of new high effective technologies of bread is connected with a necessity of solving a problem of the products quality at the discrete work of enterprises: at processing raw materials (flour) with decreased properties in ecologically unfavorable regions, manufacturing products with prolonged storage terms, high consumption characteristics, diet destination, for treating-prophylactic nutrition. The development of innovative technologies of bakery products of rye-wheat flour is based on revelation of conceptual approaches, connected with creation of new functional technological properties of dough systems and ready products. That is why in bread technologies there are searched new raw material sources, food supplements-improvers, able to raise consumption characteristics, storage terms, food value; to enrich a ready product with functional ingredients and so on. The water-retaining capacity (WRC) - is one of main functional-technological parameters of food raw materials and ready products, because it favors the output, prime cost and quality characteristics of bakery products. For increasing WRC of rye-wheat dough, there is proposed the polyfunctional food supplement "Magnetofood". For reasoning the mechanism of its interaction with polymer matrixes of lipo- and glucoproteids of rye-wheat flour and WRC mechanism of the food supplement "Magnetofood" in rye-wheat dough - there was investigated the influence of "Magnetofood" on processes of hydration, dissolution and water-retention of rye-wheat flour. It was established, that introduction of the food supplement "Magnetofood" in rye-wheat flour in amounts: 0,10; 0,15; 0,20\% of a flour mass increases its solubility and WRC: solubility - by 4,5-12,5\%; WRC - in 1,1-1,3 times, respectively. The rational dose of the food supplement "Magnetofood" is experimentally determined $-0,15 \%$ of a flour mass. There was investigated the influence of the food supplement "Magnetofood" on a quantity of bound water by experimental samples of rye-wheat flour at temperatures from 30 to $70{ }^{\circ} \mathrm{C}$. It was established, that the temperature
\end{abstract}


growth in experiments results in increasing the quantity of bound water for all experimental samples. Addition of "Magnetofood" in amounts: 0,$10 ; 0,15 ; 0,20 \%$ of a flour mass favors the increase of bound water in 1,2-1,5 times, comparing with the control (without "Magnetofood"). The received experimental data may be used at developing the technology of rye-wheat bread, enriched with the polyfunctional food supplement "Magnetofood"; and also at developing innovative technologies of food system systems (especially, meat, confectionary, milk ones). The results of the study may be used for developing recipes and technologies of food products for increasing their output, water-retaining and stabilizing capacities.

Keywords: polyfunctional food supplement "Magnetofood", rye-wheat flour, solubility, bound water, water-retaining capacity.

\section{Introduction}

Modern tendencies of the bakery industry development are directed on not only producing bakery products themselves, but also on producing bread and bakery products with increased storage terms at preserving the quality and usefulness of a final product. Introduction of innovative technological compositions becomes more effective at the detail analysis of their functional-technological properties; estimation of the influence on organoleptic, structural-mechanical and physical-chemical characteristics of a final product [1]. For today at estimating the quality and storage terms of bakery products, one of determinative physical-chemical parameters is a water-retaining capacity (WRC) as one that determines the quality, consumption characteristics, output and prime cost of ready products [2]. Diverse water-retaining agents (WA) are used at modern food enterprises. WA - are hygroscopic substances that regulate the water activity in food products. They prolong their storage terms, neutralize the influence of atmospheric air with a low humidity. They bind water in a ready product, decelerating its evaporation. Their use allows to prolong freshness of ready products. Main WA - alginates, sugar-replacers, pectin, glycerin, lactates, polyphosphates [3].

Today diverse biologically active substances of vegetable, fruit and herbal supplements [4-6], and also compounds of the biological origin: soy, chickpea, [7]; enzymes, micro-water plants and so on $[8,9]$ are used in bread technologies for increasing WRC of dough semi-products and bakery products, made of them.

The analysis of information sources [1-9] demonstrates the absence of data about polyfunctional food supplements with a complex effect that increase the water-retaining capacity of rye-wheat dough and ready products, made of it.

The aim of the research is to study hydration processes of rye-wheat flour with adding the food supplement "Magnetofood" at temperatures from 30 to $70{ }^{\circ} \mathrm{C}$, especially, the solubility, quantity of bound water, water-retaining capacity (WRC); and also the influence of the food supplement "Magnetofood" on the moisture distribution in the structure of dough systems, based on rye-wheat flour that allows to recommend it for introducing in food systems, especially rye-wheat dough semi-products.

\section{Materials and Methods}

\section{1. Studied materials and equipment, used in the experiment}

The study of the influence of the polyfunctional food supplement "Magnetofood" on the solubility, quantity of bound water and water-retaining capacity (WRC) of rye-wheat flour was realized on model systems:

- sample 1 control - rye-wheat flour according to SSTU-F 4583:2006. Ratio between peeled rye flour and wheat flour of the first sort is 60:40 according to the base recipe of the bread 'Darnitsky" [16];

- sample 2 - rye-wheat flour with the polyfunctional food supplement "Magnetofood" in amount $0,10 \%$ of a flour mass as a powder [TC U 10.8-2023017824-001:2018]. The food supplement "Magnetofood" is based on iron oxides;

- sample 3 - rye-wheat flour with the polyfunctional food supplement "Magnetofood" in amount $0,15 \%$ of a flour mass as a powder; 
- sample 4 - rye-wheat flour with the polyfunctional food supplement "Magnetofood" in amount $0,20 \%$ of a flour mass as a powder.

Experimental samples of rye-wheat flour are presented on Fig. 1.

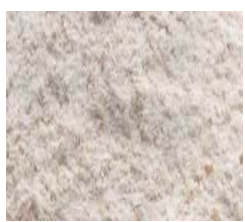

$a$

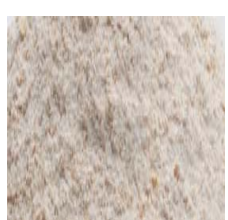

$b$

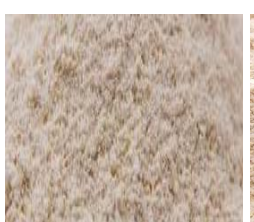

$c$

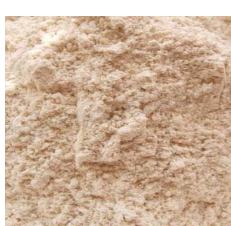

$d$

Fig. 1. Experimental samples of rye-wheat flour: $a$-sample $1 ; b$-sample $2 ; c$ - sample $3 ; d$-sample 4

The flour mass was determined on analytic scales, series ANG (Ukraine), the solubility of bound water and water-retaining capacity (WRC) were determined by a mixer, model ПE-8100 (producer Ecros, group of companies) and centrifuge, trademark CM-6M with a rotor 6M (made by «ELMI» Latvia).

The devices, used for studying physical-chemical properties of the experimental samples of rye-wheat flour are on Fig. 2.

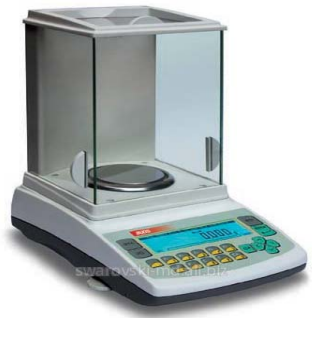

$a$

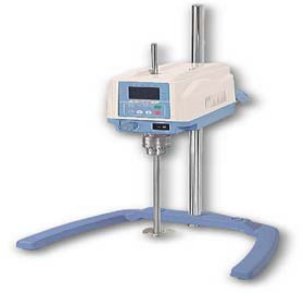

$b$

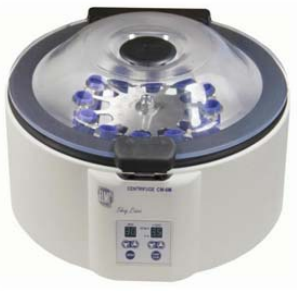

$c$

Fig. 2. Devices, used for studying parameters of dough and bread: $a$-electric analytic scales ANG; $b$ - laboratory mixer, model ПE-8100; $c$ - centrifuge, trademark CM-6M with a mixer 6M

\section{2. Methods of determining physical-chemical indices}

The work studies the following chemical and functional-technological properties: water-retaining capacity (WRC), solubility, quantity of bound water. There are the most important parameters that demonstrate a possibility of rye-wheat bread, enriched with "Magnetofood", to bound water and to be dissolved in it. They also influence the assimilability, storage term and consumption qualities of a ready product. The standard research methods, considered below $[17,18]$ and SSTU-F 4583:2006, were used in the experiment.

WRC (in $\mathrm{g} / \mathrm{g}$ ) was determined by Shoh's method as a quantity of absorption water, retained by a raw material component in the process of keeping and centrifuging water suspension. Solubility - P (in \%) and quantity of bound water - W (in g) were also determined by Shoh's method [17, 18].

Analysis course: the product batch of $0,8 \mathrm{~g}$ was poured with $40 \mathrm{ml}$ of distilled water, kept in the water excess at continuous mixing during $30 \mathrm{~min}$, at temperatures from 30 to $70{ }^{\circ} \mathrm{C}$, then transferred in a centrifuge test tube and centrifuged during 5 min at 4500 turns/ min. A liquid phase was poured in a measuring test tube and the content of dry substances in filtrate was determined. Solubility $\mathrm{P}$ in $\%$ of dry substances of flour was determined by the ratio of the mass of the liquid phase of the system in grams and the content of dry substances in filtrate to the batch mass. The quantity of bound water - W (in g) was determined by weighing the test tube with a residue, excluding the mass of the empty test tube and batch. WRC (in $\mathrm{g} / \mathrm{g}$ ) was determined by the ratio of the quantity of bound water W to the batch mass. 


\section{Results}

The research methods, considered in section 2, have a practical use at studying physical-chemical and functional-technological characteristics, especially, the solubility, quantity of bound water, water-retaining capacity of rye-wheat flour.

The data on the solubility, WRC of the experimental samples of rye-wheat flour with adding "Magnetofood" comparing with the control, and also quantity of bound water in experimental samples, are presented on Fig. 3-5.

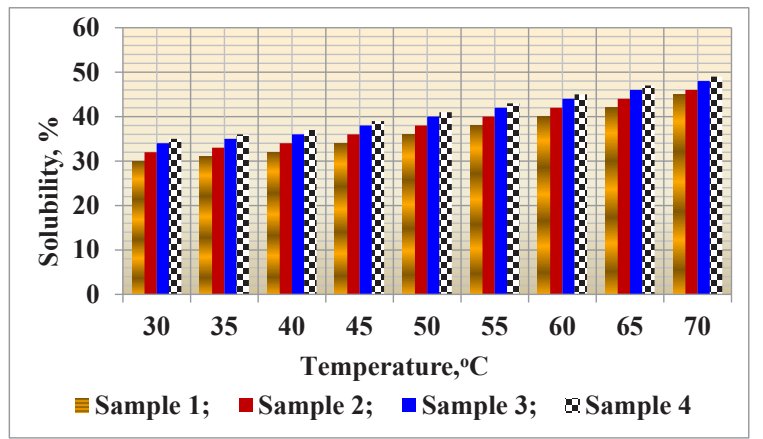

Fig. 3. Solubility of the experimental samples of rye-wheat flour depending on temperature

The analysis of the data of Fig. 3 demonstrates that the dynamics of the solubility growth with an increasing temperature is observed for all experimental samples of ryewheat flour. But the flour experimental samples, enriched with "Magnetofood" food supplement demonstrate the higher solubility by 4,5-12,5\% at all temperatures, comparing with the control.

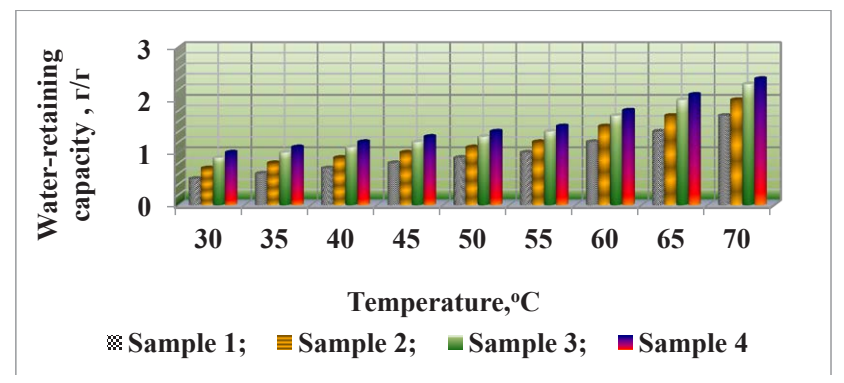

Fig. 4. Dependence of the water-retaining capacity of the experimental samples of rye-wheat flour on temperature

The experimental data of Fig. 4 demonstrate that at the temperature increase from 30 to $70{ }^{\circ} \mathrm{C}$, the water-retaining capacity grows in all experimental samples of flour. Moreover, addition of "Magnetofood" supplement favors WRC increase at the experimental temperatures in $1,1-1,3$ times comparing with the control sample.

The analysis of the experimental data of Fig. 5 demonstrates that at the temperature increase from 30 to $70^{\circ} \mathrm{C}$, the quantity of bound water grows in all experimental samples of flour. Addition of "Magnetofood" in rye-wheat flour in amounts: 0,$10 ; 0,15 ; 0,20 \%$ of a flour mass favors the increase of the bound water quantity at the experimental temperatures in 1,2-1,5 times, comparing with the control.

It is connected with an ability of ionized nanoparticles of the food supplement "Magnetofood" to change the spatial construction of biopolymer matrixes of rye-wheat flour, favoring the solubility intensification and increase of WRC of flour.

Fig. 6 presents microscopic studies of the influence of the food supplement "Magnetofood" on the moisture distribution in the structure of dough systems, based on rye-wheat flour. 


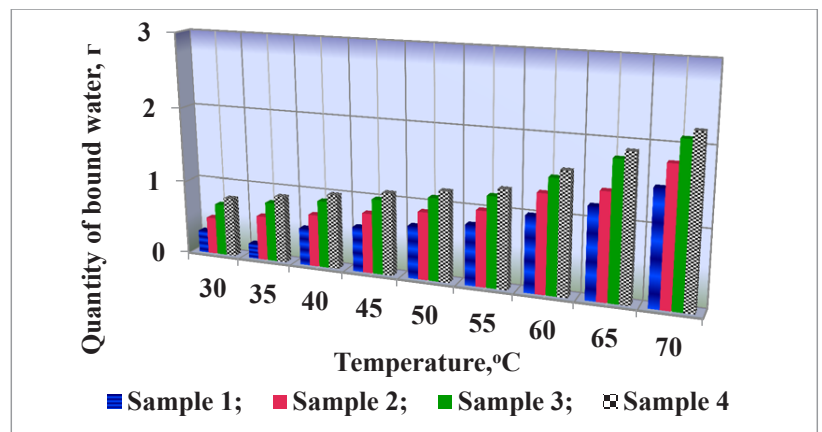

Fig. 5. Dependence of the quantity of bound water of the experimental samples of rye-wheat flour on temperature

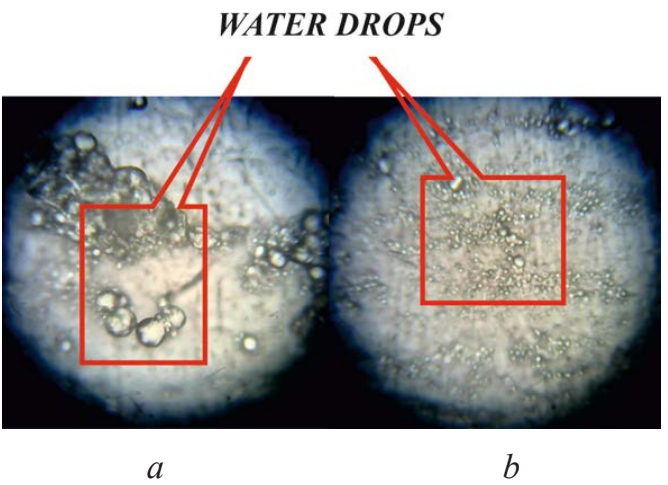

Fig. 6. Influence of the food supplement "Magnetofood" on the moisture distribution in the structure of dough systems, based on rye-wheat flour:

$a$-sample 1 control - dough system, based on rye-wheat flour without "Magnetofood" food supplement; $b$ - sample 3 - dough system based on rye-wheat flour with "Magnetofood" food supplement in optimal amount $-0,15 \%$ of a flour mass

The microphotos (Fig. 6) testify that many small water drops concentrate around "Magnetofood" nanoparticles. Big drops, unevenly distributed by the volume of the dough system of the control sample, are observed in sample 1 (without "Magnetofood").

Thus, the experimental samples of rye-wheat flour, enriched with "Magnetofood" demonstrate the high WRC and bound the great amount of water, evenly distributed along the whole volume of the dough system. It gives a possibility to use "Magnetofood" supplement for baking bread and bakery products.

The research results prove the presence of the important functional-technological property water-retaining capacity in "Magnetofood" food supplement. The received experimental data may be used in the technology of rye-wheat bread, enriched with the food supplement "Magnetofood", for getting products with high consumption characteristics and prolonged storage terms.

\section{Conclusions}

The research methods of flour and model systems on its base, presented in the work, may be used at studying the influence of diverse food supplements, especially, solubility and water-retaining capacity of food raw materials, semi-products and ready products.

Using the considered methodologies in the future, scientists may investigate more detail the influence of different food ingredients on the solubility, viscosity, quantity of bound water, water-retaining capacity of food systems, based on flour and also ready products; to study hydration, dissolution processes, stabilization of the structure of biopolymer matrixes more detail.

The shortcoming of this work is a fact that the effect of the proposed method is considered only on the one type of model systems - rye-wheat one and influence of only one food supplement - polyfunctional food supplement "Magnetofood" is investigated. So, it is unknown, how this 
supplement influences technological parameters of dough systems of other recipe compositions (of other types and sorts of flour).

The positive moment is that the proposed research methods may be used at studying physical-chemical and functional-technological characteristics, especially, the solubility, quantity of bound water, water-retaining capacity of not only rye-wheat dough systems and ready products, but also rye, wheat and so on. At the same time the research results may be used in the technology of rye-wheat bread and bakery

\section{References}

[1] Semenenko, O. G. (2017). Analiz razvitiya pishchevoy promyshlennosti Ukrainy. Ekonomichnyi visnyk universytetu, 33/1, 169-181.

[2] Marmuzova, L. V. (2012). Tekhnologiya hlebopekarnogo proizvodstva. Syr'e i materialy. Moscow: Akademiya, 288.

[3] Sokol, N. V., Shcherbakova, E. V., Krasnoselova, E. A., Donchenko, L. V. (2018). Pishchevaya himiya. Dobavki. Krasnodar: KGAU im. akad. I. T. Trubilina, 223.

[4] García-Segovia, P., Pagán-Moreno, M. J., Lara, I. F., Martínez-Monzó, J. (2017). Effect of microalgae incorporation on physicochemical and textural properties in wheat bread formulation. Food Science and Technology International, 23 (5), 437-447. doi: https://doi.org/10.1177/1082013217700259

[5] Citrusovye volokna Herbacel AQ Plus - tip N. Specifikacii dlya pishchevyh dobavok i receptury. Available at: http://specin.ru

[6] Chugunova, O. V., Pastushkova, E. V. (2015). Modeling of organoleptic indicators of bread with plant supplements. Bulletin of the South Ural State University. Series Food and Biotechnology, 3 (4), 80-87. doi: https://doi.org/10.14529/food150411

[7] Bird, L. G., Pilkington, C. L., Saputra, A., Serventi, L. (2017). Products of chickpea processing as texture improvers in gluten-free bread. Food Science and Technology International, 23 (8), 690-698. doi: https://doi.org/10.1177/1082013217717802

[8] Boubaker, M., Omri, A. E., Blecker, C., Bouzouita, N. (2016). Fibre concentrate from artichoke (Cynara scolymus L.) stem by-products: Characterization and application as a bakery product ingredient. Food Science and Technology International, 22 (8), 759-768. doi: https://doi.org/10.1177/1082013216654598

[9] Ngemakwe, P. N., Le Roes-Hill, M., Jideani, V. (2014). Advances in gluten-free bread technology. Food Science and Technology International, 21 (4), 256-276. doi: https://oi.org/10.1177/1082013214531425

[10] Tsykhanovska, I., Evlash, V., Alexandrov, A., Svidlo, K., Gontar, T. (2017). Influence of the polyfunctional food supplement "Magnetofood" on the quality of the wheat-rye bread "Kharkiv Rodnichok" in the storage process. Eastern-European Journal of Enterprise Technologies, 5 (11 (89)), 61-70. doi: https:// doi.org/10.15587/1729-4061.2017.111522

[11] Tsykhanovska, I., Evlash, V., Alexandrov, A., Svidlo, K., Gontar, T. (2017). Research quality of the wheat-rye bread with addition of the polyfunctional food supplement «Magnetofood». EUREKA: Life Sciences, 5, 45-52. doi: https://doi.org/10.21303/2504-5695.2017.00431

[12] Tsykhanovska, I., Evlash, V., Alexandrov, A., Lazarieva, T., Svidlo, K., Gontar, T. (2017). Design of technology for the rye-wheat bread "Kharkivski rodnichok" with the addition of polyfunctional food additive "Magnetofood." Eastern-European Journal of Enterprise Technologies, 6 (11 (90)), 48-58. doi: https://doi.org/10.15587/1729-4061.2017.117279

[13] Tsykhanovska, I., Evlash, V., Alexandrov, A., Lazareva, T., Svidlo, K., Gontar, T. (2017). Research into technological indicators of a rye-wheat dough semi-finished product with the addition of the polyfunctional food supplement "Magnetofood." EUREKA: Life Sciences, 6, 43-50. doi: https:// doi.org/10.21303/2504-5695.2017.00511

[14] Tsykhanovska, I., Evlash, V., Alexandrov, A., Lazarieva, T., Svidlo, K., Gontar, T. et. al. (2018). Substantiation of the mechanism of interaction between biopolymers of ryeandwheat flour and the nanoparticles of the magnetofood food additive in order to improve moistureretaining capacity of dough. Eastern-European Journal of Enterprise Technologies, 2 (11 (92)), 70-80. doi: https://doi.org/10.15587/1729-4061.2018.126358

[15] Tsykhanovska, I., Evlash, V., Alexandrov, A., Lazareva, T., Svidlo, K., Gontar, T. et. al. (2018). Investigation of the moisture-retaining power of rye-wheat gluten and flour with polyfunctional food supplement “Magnetofood.” EUREKA: Life Sciences, 2, 67-76. doi: https://doi.org/10.21303/2504-5695.2018.00611

[16] Ershov, P. S. (2004). Sbornik receptur na hleb i hlebobulochnye izdeliya. Sankt-Peterburg: Profi-inform, 190.

[17] Koryachkina, S. Ya., Berezina, N. A., Hmeleva, E. V. (2011). Metody issledovaniya svoystv syr'ya, polufabrikatov i gotovoy produkcii. Metody issledovaniya svoystv rastitel'nogo syr'ya. Orel: FGOU VPO «Gosuniversitet-UNPK», 297.

[18] Rihter, M., Augustat, Z., Shirbaum, F. (1975). Izbrannye metody issledovaniya krahmala. Moscow: Pishchevaya promyshlennost', 183. 